\title{
Stimulatory and Inhibitory Effects of Cyclic AMP on Pancreatic Glucagon Release from Monolayer Cultures and the Controlling Role of Calcium
}

\author{
C. B. Wollheim, B. Blondel, A. E. Renold and G. W. G. Sharp \\ Institut de Biochimie Clinique and Institut d'Histologie et d'Embryologie, \\ Université de Genève, Genève, Switzerland
}

Summary. When glucagon release from monolayer cultures of newborn rat pancreas was measured over four hours in media containing $2.5 \mathrm{mM} \mathrm{Ca}^{++}$, a significant cyclic AMP-related inhibition of release was observed. This was noted whether intracellular cyclic AMP levels were raised by the addition of exogenous cyclic AMP or dibutyryl cyclic AMP, by phosphodiesterase inhibition with theophylline, or by the stimulation of adenylate cyclase with cholera toxin. The inhibition was concentration dependent for cyclic AMP and could not be reproduced by the addition of AMP, ADP or ATP. Adenosine also inhibited glucagon release while ATP was stimulatory. From time course studies it appeared that the inhibitory effects of cyclic AMP and cholera toxin were progressive after two hours of incubation. With cholera toxin an early stimulation of glucagon release was observed. The effects of cyclic AMP and cholera toxin on argininestimulated glucagon release were to stimulate further the glucagon release during the first hour of the incubation. Thus, the effects of raising intracellular cyclic AMP levels were biphasic in that both an early stimulation and a late inhibition of glucagon release were observed. In examining the nature of these responses a remarkable controlling role for $\mathrm{Ca}^{++}$was uncovered: at $\mathrm{Ca}^{++}$concentrations of $0.3 \mathrm{mM}$ and lower no effect of cyclic AMP on glucagon release was found. With $1 \mathrm{mM} \mathrm{Ca}^{++}$in the medium cyclic AMP stimulated glucagon release early $(30 \mathrm{~min})$ and thereafter had no further effect. In the presence of $2.5 \mathrm{mM}$ $\mathrm{Ca}^{++}$cyclic AMP did not stimulate early but did cause the delayed inhibition of release. It is concluded that the effect of cyclic AMP on glucagon release can be either stimulatory or inhibitory depending upon the $\mathrm{Ca}^{++}$concentration of the medium and the duration of exposure to raised cyclic AMP levels.

Key words: Monolayer culture, glucagon release, cyclic AMP, $\mathrm{Ca}^{++}$, cholera toxin.
The release of the catabolic hormone glucagon is stimulated by stress-associated states $[1,2,3,4]$, physical exercise $[5,6,7]$ and hypoglycemia $[8,9,10$, 11 ], as well as during infections [12], diabetic ketoacidosis $[13,14]$ and starvation $[15,16]$. This stimulation of release is caused, at least in part, by activation of the autonomic nervous system. Excitation of both parasympathetic $[11,17]$ and sympathetic nerves $[18,19]$ to the pancreas causes glucagon release. Acetyl choline stimulates glucagon release in vitro [20], catecholamines stimulate release in vitro $[21,22,23,24,25]$ and in vivo $[26,27,28,29]$. The catecholamine effects appear to be mediated by $\beta$-adrenergic receptors. Thus, the $\beta$-agonist isoproterenol stimulates glucagon release $[22,25,28]$ and $\beta$-adrenergic blocking agents attenuate the response to nerve stimulation in the dog [30], also that to exsanguination [31], to non-exhaustive physical exercise [7], to epinephrine in vitro [22], to isoproterenol in vivo [28] and in vitro [22]. The concept is supported further by the finding that epinephrine stimulates adenylate cyclase in homogenates of A cell-rich islets from streptozotocin treated guinea-pigs [32].

Cyclic AMP, the intracellular mediator of $\beta$-adrenergic effects, has also been widely reported to stimulate glucagon release. This has been shown with cyclic AMP [33, 34, 35], dibutyryl cyclic AMP [32, 35, 36 , and by raising intracellular cyclic AMP levels with theophylline $[24,32,35,36,37,38]$. By contrast, our own data [39] showed consistent inhibition of glucagon release with cyclic AMP or theophylline in monolayer cultures of newborn rat pancreas. In a recent report [40] dibutyryl cyclic AMP was shown to inhibit glucagon release in the perfused pancreas of the rat. Comparison of our early data, in which inhibitory effects were found, with those of others demonstrating stimulatory effects, uncovered differences in the imposed experimental conditions. Firstly, the inhibitory effects were seen with rather lengthy incubations of 
four hours. Secondly, the $\mathrm{Ca}^{++}$concentration of the media was higher $(2.5 \mathrm{mM})$ than in studies reporting stimulation by cyclic AMP $[32,36]$ or the effective, free $\mathrm{Ca}^{++}$concentration in the latter was in effect lowered by higher albumin concentrations in the media $[25,38]$. Consequently, the studies reported here were performed to document fully the inhibitory effects of cyclic AMP and to investigate the time course of the response. Furthermore, the influence of different concentrations of $\mathrm{Ca}^{++}$in the medium was studied. In view of the need to use high and necessarily unphysiological concentrations of cyclic AMP on intact tissues and cells, additional studies were performed using two other agents to raise intracellular cyclic AMP levels. These were theophylline, which acts by inhibition of phosphodiesterase, and cholera toxin, which is a specific, and ubiquitous stimulator of adenylate cyclase, and which has been reported to stimulate the accumulation of cyclic AMP in isolated islets of Langerhans [41].

\section{Material and Methods}

The monolayer culture technique of endocrine pancreatic cells from 1-3 day old rats has been described in detail elsewhere $[42,23,43]$. In brief, the enzymatically dissociated cells were plated into plastic Petri dishes. 75-150 rats were used for one culture preparation, yielding 30 to 60 Petri dishes. To reduce the number of fibroblastoid cells, which attach more rapidly to the bottom of the Petri dishes, the cells in suspension were decanted into new Petri dishes at $14 \mathrm{~h}$ of culture. At approximately $44 \mathrm{~h}$ after the original plating, at a time when the endocrine cells had firmly attached to the bottom of the dishes and had rearranged into clusters of varying size, the cultures were washed carefully and fresh culture medium was added. The culture medium 199 was supplemented with $14 \mathrm{mM}$ sodium bicarbonate, $10 \%$ calf serum and 400 $\mathrm{U} / \mathrm{ml}$ sodium penicillin. The glucose concentration of the culture medium was $16.7 \mathrm{mM}$ until the first medium change after washing (44 h after plating) when it was decreased to $5.6 \mathrm{mM}$ for the last $20-24 \mathrm{~h}$ prior to the incubation experiments. Culture and incubation experiments were carried out at $37^{\circ} \mathrm{C}$ in an atmosphere saturated with water and a $\mathrm{pH}$ monitored to $7.40 \pm 0.05$ by varying the $\mathrm{CO}_{2}$ flow to the incubator. All experiments were performed on the third day of culture, a time at which the remaining exocrine cells in culture are devoid of zymogen granules as evidenced by electron microscopy [44] and when amylase is not detectable in the bathing medium.

Incubation experiments were performed in KrebsRinger bicarbonate buffer (KRB) with the following ionic composition: $\mathrm{NaCl} 118.6 \mathrm{mM}, \mathrm{KCl} 4.8 \mathrm{mM}$, $\mathrm{KH}_{2} \mathrm{PO}_{4} 1.2 \mathrm{mM}, \mathrm{NaHCO}_{3} 24.6 \mathrm{mM}, \mathrm{Mg} \mathrm{SO} \mathrm{S}_{4} 1.2$ $\mathrm{mM}$ and $\mathrm{CaCl}_{2}$ (when not otherwise stated) $2.5 \mathrm{mM}$. The KRB medium contained $0.5 \%$ dialyzed bovine serum albumin, 250 kallikrein inhibitory units $/ \mathrm{ml}$ Trasylol, 2.8 or $16.7 \mathrm{mM}$ glucose, with or without the agents under study. The bovine serum albumin employed (fraction V, $80 \%$ pure) contained free fatty acids yielding a maximal final concentration in the KRB-buffer of about $0.2 \mathrm{mM}$. Prior to incubation the cultured cells were washed three times, after which 3 or $5 \mathrm{ml}$ incubation buffer was added to each Petri dish. Incubations were carried out over 2 to $4 \mathrm{~h}$ and, in some experiments, 0.5 or $1 \mathrm{ml}$ aliquots were removed at other times, as specified. Samples were kept at $-20^{\circ} \mathrm{C}$ until assay. Immunoreactive glucagon (IRG) was measured by the method of Unger et al. [45] using pork glucagon as standard, and antipork glucagon serum obtained from rabbit $30 \mathrm{~K}$. This antiserum is relatively specific for pancreatic glucagon. None of the substances tested in this study interfered with the glucagon assay. Cholera toxin was dissolved in sterile water and kept at $+4{ }^{\circ} \mathrm{C}$.

The Petri dishes within a single culture preparation were paired for statistical analysis using Student's t-test. The data from experiments under identical conditions but performed on different occasions were pooled for statistical analysis. Where an occasional Petri dish was lost its pair was deleted from analysis.

The materials employed and their sources were as follows: trypsin (Difco Laboratories, Detroit, Mich., U.S.A.), collagenase (Worthington Biochemical Corporation, Freehold, N. J., U.S.A.), medium 199 (Grand Island Biochemicals Co., Grand Island, N. Y., U.S.A.), sodium penicillin G (Chas. Pfizer and Co. Inc., New York, N. Y., U.S.A.), $60 \mathrm{~mm}$ diameter plastic Petri dishes (Falcon Plastics, Oxnard, Calif., U.S.A.), Trasylol (kindly supplied by Dr. Ruff, Bayer Pharma A.G., Zürich, Switzerland), bovine serum albumin (Behringwerke A.G., Marburg, FRG), glucose, 1-arginine monohydrochloride, theophylline (Merck A.G., Darmstadt, FRG), N-2-O-Dibutyryladenosine $3^{\prime}, 5^{\prime}$-cyclic monophosphate monosodium salt (DBcAMP), adenosine $3^{\prime}, 5^{\prime}$-cyclic monophosphate (cAMP), adenosine, adenosine $5^{\prime}$ monophosphate disodium salt (AMP), adenosine 5' diphosphate, disodium salt (ADP) and adenosine $5^{\prime}$ triphosphate, disodium salt (ATP) (Boehringer Mannheim G.m.b.H., Mannheim, FRG), purified [46] cholera toxin lot no 0572 was kindly supplied by Dr. C. Miller (National Institute of Allergy and Infectious Diseases (NIAID), NIH, Baltimore, Md, U.S.A.). The cholera toxin was prepared under contract for the NIAID by R. A. Finkelstein, Ph. D. (The University of Texas Southwestern Medical School, Dallas, Texas, 
Table 1. Effect of cyclic AMP, dibutyryl cyclic AMP, theophylline and cholera toxin on glucagon release $A$ : in the presence of $2.8 \mathrm{mM}$ glucose, and $B$ : in the presence of $16.7 \mathrm{mM}$ glucose. Results are expressed as $\mathrm{ng} \mathrm{IRG} / \mathrm{dish} / 4 \mathrm{~h}$

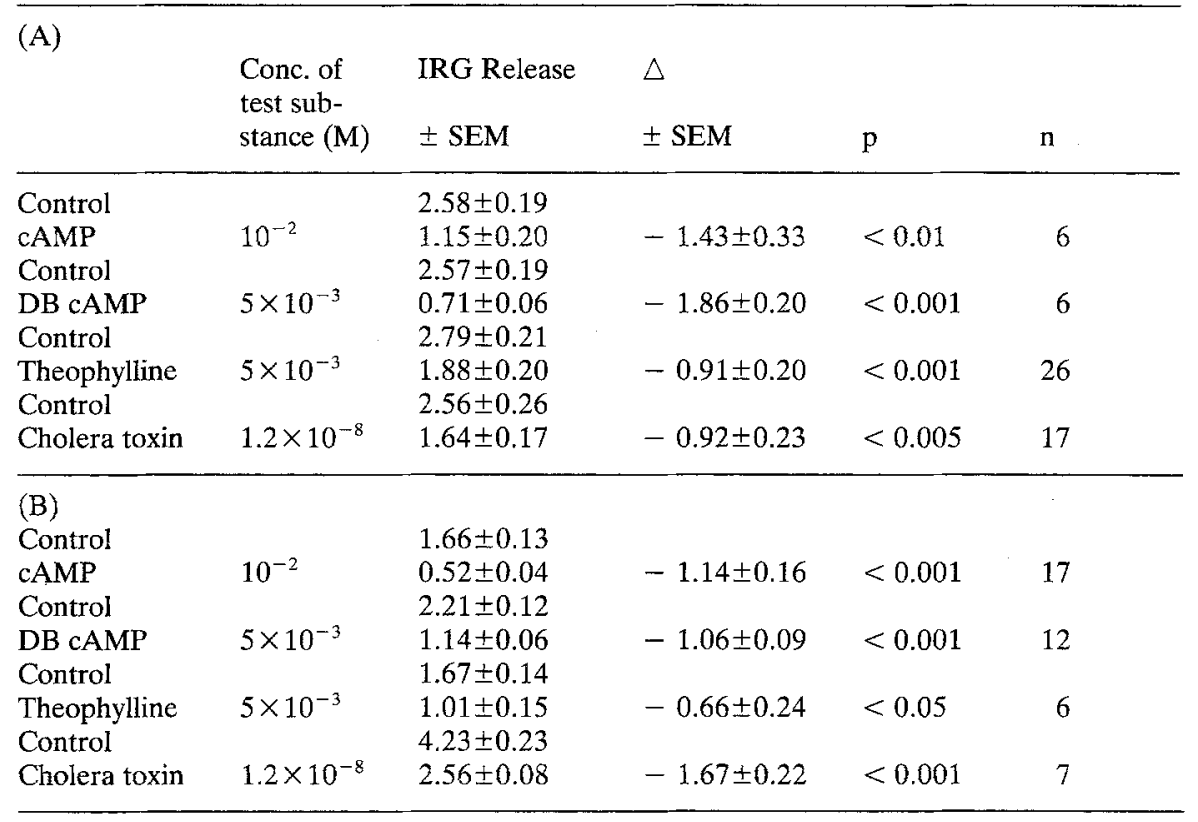

U.S.A.). Pork glucagon was kindly provided by Dr. L. Heding (Novo Research Institute, Copenhagen, Denmark) and glucagon antiserum $30 \mathrm{~K}$ was the generous gift of Dr. R. Unger (Department of Internal Medicine, the University of Texas Southwestern Medical School at Dallas and Veterans Administration Hospital, Dallas, Texas, U.S.A.).

\section{Results}

\section{a. Effects of Agents which Raise Intracellular Cyclic AMP Levels}

When the monolayer cultures were incubated over $4 \mathrm{~h}$ in the presence of either $10 \mathrm{mM}$ cyclic AMP or $5 \mathrm{mM}$ dibutyryl cyclic AMP, glucagon release was significantly inhibited relative to control cultures (Table 1 A). Similarly, when endogenous cyclic AMP levels were elevated, either by the phosphodiesterase inhibitor theophylline $(5 \mathrm{mM})$ or by $1.2 \times 10^{-8} \mathrm{M}$ cholera toxin $(1 \mu \mathrm{g} / \mathrm{ml})$, glucagon release over $4 \mathrm{~h}$ was inhibited (Table $1 \mathrm{~A}$ ). These experiments were carried out in the presence of $2.8 \mathrm{mM}$ glucose at which low concentration glucagon release is elevated. When the experiments were repeated in the presence of a high glucose concentration, inhibitory to glucagon release, further inhibition was observed with all four agents. Thus, in Table $1 \mathrm{~B}$, cyclic AMP, dibutyryl cyclic AMP, theophylline and cholera toxin can all be seen to reduce markedly the amount of glucagon secreted. With low glucose, the inhibition was $56 \%$ for cyclic AMP, $72 \%$ for dibutyryl cyclic AMP, 33\% for theophylline and $35 \%$ for cholera toxin. With high glucose, the inhibition was $69 \%$ for cyclic AMP, $48 \%$ for dibutyryl cyclic AMP and $40 \%$ for both theophylline and cholera toxin.

\section{b. Dose-Response Characteristics of the Inhibitory Effects of Cyclic AMP and Cholera Toxin}

Cyclic AMP was added to the medium bathing the cells at three concentrations, $0.1,1$ and $10 \mathrm{mM}$, in the presence of $2.8 \mathrm{mM}$ glucose. The results of these experiments are expressed as \% inhibition of glucagon release measured over $4 \mathrm{~h}$. All three concentrations caused significant inhibition of glucagon release. Inhibition with $0.1 \mathrm{mM}$ was $12 \%(p<0.02, \mathrm{n}=6)$, with $1.0 \mathrm{mM} 29 \%(p<0.005, \mathrm{n}=6)$ and with $10 \mathrm{mM} 49 \%$ $(p<0.001, \mathrm{n}=5)$.

Cholera toxin was also tested at three concentrations, $1.2 \times 10^{-10}, 1.2 \times 10^{-9}$ and $1.2 \times 10^{-8} \mathrm{M}$ in the presence of $2.8 \mathrm{mM}$ glucose. $1.2 \times 10^{-10} \mathrm{M}$ cholera toxin did not significantly inhibit glucagon release although the release was depressed by $18 \%(p<0.2$, $\mathrm{n}=4)$. The two higher concentrations of toxin did inhibit significantly, $1.2 \times 10^{-9} \mathrm{M}$ by $41 \%(p<0.01$, $\mathrm{n}=4)$ and $1.2 \times 10^{-8} \mathrm{M}$ by $48 \%(p<0.005, \mathrm{n}=4)$. 
Table 2. Effects of adenosine and different adenine nucleotides on glucagon release in the presence of either $2.8 \mathrm{mM}$ or $16.7 \mathrm{mM}$ glucose. Cyclic AMP, adenosine, AMP, ADP and ATP were used at a concentration of $10 \mathrm{mM}$. Results are expressed as $\mathrm{ng}$ IRG/dish $/ 4 \mathrm{~h}$

\begin{tabular}{|c|c|c|c|c|}
\hline $\begin{array}{l}\text { Glucose } \\
(\mathrm{mM})\end{array}$ & $\begin{array}{l}\text { Test substance } \\
(10 \mathrm{mM})\end{array}$ & $\begin{array}{l}\text { IRG release } \\
\pm \mathrm{SEM}\end{array}$ & $\begin{array}{l}\triangle \\
\pm \text { SEM } \\
\text { (compared to }\end{array}$ & $\begin{array}{l}\triangle \\
\pm \text { SEM } \\
\text { (compared to } 16.7 \mathrm{mM} \text { glucose) }\end{array}$ \\
\hline
\end{tabular}

\begin{tabular}{|c|c|c|c|c|c|c|c|}
\hline \multicolumn{8}{|l|}{ (A) } \\
\hline 2.8 & - & $0.64 \pm 0.05$ & & & & & 5 \\
\hline 2.8 & cAMP & $0.39 \pm 0.05$ & $-0.26 \pm 0.07$ & $<0.025$ & & & 5 \\
\hline 2.8 & Adenosine & $0.35 \pm 0.06$ & $-0.29 \pm 0.05$ & $<0.02$ & & & 5 \\
\hline 2.8 & AMP & $0.63 \pm 0.05$ & $-0.01 \pm 0.06$ & $<0.95$ & & & 5 \\
\hline 2.8 & ADP & $0.66 \pm 0.07$ & $0.02 \pm 0.10$ & $<0.90$ & & & 5 \\
\hline 2.8 & ATP & $1.42 \pm 0.19$ & $0.78 \pm 0.17$ & $<0.02$ & & & 5 \\
\hline \multicolumn{8}{|l|}{ (B) } \\
\hline 2.8 & - & $1.13 \pm 0.13$ & & & & & 6 \\
\hline 16.7 & - & $0.86 \pm 0.03$ & $-0.27 \pm 0.06$ & $<0.01$ & & & 6 \\
\hline 2.8 & Adenosine & $0.73 \pm 0.05$ & $-0.40 \pm 0.10$ & $<0.01$ & & & 6 \\
\hline 16.7 & Adenosine & $0.79 \pm 0.07$ & & & $-0.06 \pm 0.03$ & $<0.10$ & 6 \\
\hline 2.8 & ATP & $1.49 \pm 0.09$ & $0.36 \pm 0.08$ & $<0.01$ & & & 6 \\
\hline 16.7 & ATP & $1.76 \pm 0.05$ & & & $0.90 \pm 0.11$ & $<0.001$ & 6 \\
\hline
\end{tabular}

\section{c. The Effects of Different Adenine Nucleotides}

The experiments were performed to compare the effects of cyclic AMP, adenosine, AMP, ADP and ATP on glucagon release over four hours. In the presence of $2.8 \mathrm{mM}$ glucose no effects were detected with AMP or ADP at a concentration of $10 \mathrm{mM}$. Adenosine at the same concentration, however, caused an inhibition of glucagon release similar to that caused by cyclic AMP. By contrast, $10 \mathrm{mM}$ ATP stimulated glucagon release to a level more than double that of the control release. These results are presented in Table 2 (A).

In a further series of experiments the effects of adenosine and ATP on glucagon release were examined. From the results presented in Table 2 (B) it can be seen that while adenosine inhibited glucagon secretion in the presence of $2.8 \mathrm{mM}$ glucose, there was no significant effect on the suppressed glucagon release in the presence of $16.7 \mathrm{mM}$ glucose. The stimulatory effect of ATP was observed in the presence of both low and high glucose concentrations and the effect was greater at $16.7 \mathrm{mM}$ than at $2.8 \mathrm{mM}$ glucose. The results in Table 2 show that with the exception of adenosine, none of the adenine nucleotides tested was capable of mimicking the cyclic AMP-induced inhibition of glucagon release. It can be seen also that in these experiments the well known inhibition of glucagon release by high glucose concentrations was confirmed.

\section{d. Effect of Cyclic AMP on Arginine-Stimulated Glucagon Release}

In order to study the effects of cyclic AMP on arginine-stimulated glucagon release, time course ex- periments were performed for various periods up to four hours in the presence of $2.8 \mathrm{mM}$ glucose and 10 $\mathrm{mM}$ arginine. As shown in Fig. 1, $10 \mathrm{mM}$ arginine stimulated glucagon release significantly at all time points (30 min, $p<0.01 ; 1,2,3$ and $4 \mathrm{~h}, p<0.005$ ). When $10 \mathrm{mM}$ cyclic AMP and arginine were added together, cyclic AMP induced a further stimulation of glucagon release. The stimulation was most marked over the first $30 \mathrm{~min}$ so that cumulative glucagon release was significantly stimulated at $30 \mathrm{~min}, 1$ and $2 \mathrm{~h}$. Release rates were not significantly stimulated after the first hour.

\section{e. Time Course of the Effect of Cholera Toxin}

Time course studies with cholera toxin revealed a biphasic pattern of effects on glucagon release. The results are shown in Fig. 2. The experiments were performed in the presence and absence of $1.2 \times$ $10^{-8} \mathrm{M}$ cholera toxin. The toxin stimulated glucagon release significantly at $30 \mathrm{~min}(p<0.05)$ and at $60 \mathrm{~min}$ $(p<0.005)$. Thereafter the rate of glucagon release in the presence of the toxin decreased so that even the cumulative glucagon release was significantly inhibited at $3 \mathrm{~h}(p<0.01)$ and $4 \mathrm{~h}(p<0.005)$.

\section{f. Effect of Cholera Toxin on Arginine-Stimulated Glucagon Release}

Three sets of conditions were used to examine the interaction of cholera toxin and arginine on glucagon release. All media contained $2.8 \mathrm{mM}$ glucose. One set of cultures was used as control, one was exposed to $10 \mathrm{mM}$ arginine and the third set to the combination of $10 \mathrm{mM}$ arginine and $1.2 \times 10^{-8} \mathrm{M}$ cholera toxin. The 


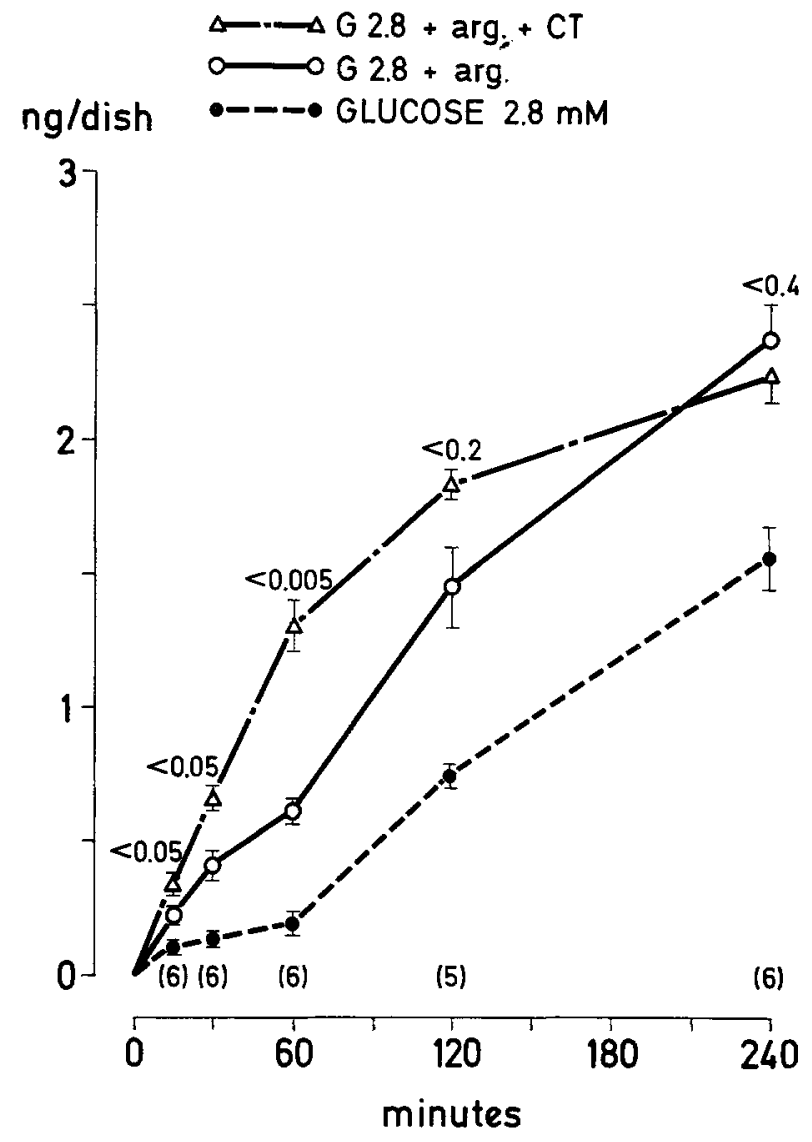

Fig. 1. Time course of the effect of cyclic AMP on arginine-stimulated glucagon release. Arginine and cyclic AMP were employed at $10 \mathrm{mM}$ concentrations in the presence of $2.8 \mathrm{mM}$ glucose and 2.5 $\mathrm{mM} \mathrm{Ca}^{++}$. Vertical lines represent $\pm \mathrm{SEM}$. The $\mathrm{p}$ values above the lines were obtained by paired comparison of the differences in glucagon release in the presence of either arginine alone or the combination of arginine and cyclic AMP. Statistical analysis of the effect of arginine relative to $2.8 \mathrm{mM}$ glucose is given in the text. The number of experiments is indicated in parenthesis

results are shown in Fig. 3. As found previously, arginine stimulated glucagon release at all time points. At $15 \mathrm{~min}$ the $p$ value was $<0.05$, at $30 \mathrm{~min}<0.01$, at $1 \mathrm{~h}<0.005$ and at 2 and $4 \mathrm{~h}<0.01$. Cholera toxin caused a further stimulation of the arginine stimulated release, but this was apparent only at the early time points up to one hour. In this respect the results are similar to those obtained with cyclic AMP. After one hour the release rates were decreased by cholera toxin so that the cumulative glucagon released at 2 and $4 \mathrm{~h}$ in the presence of arginine and cholera toxin was not different from that released by arginine alone.

\section{g. Effect of Cyclic AMP in the Presence of Different Concentrations of $\mathrm{Ca}^{++}$}

As all the experiments reported so far were performed in the presence of $2.5 \mathrm{mM} \mathrm{Ca}^{++}$and because $\mathrm{Ca}^{++}$ has both stimulatory and inhibitory effects on gluca- ng/dish

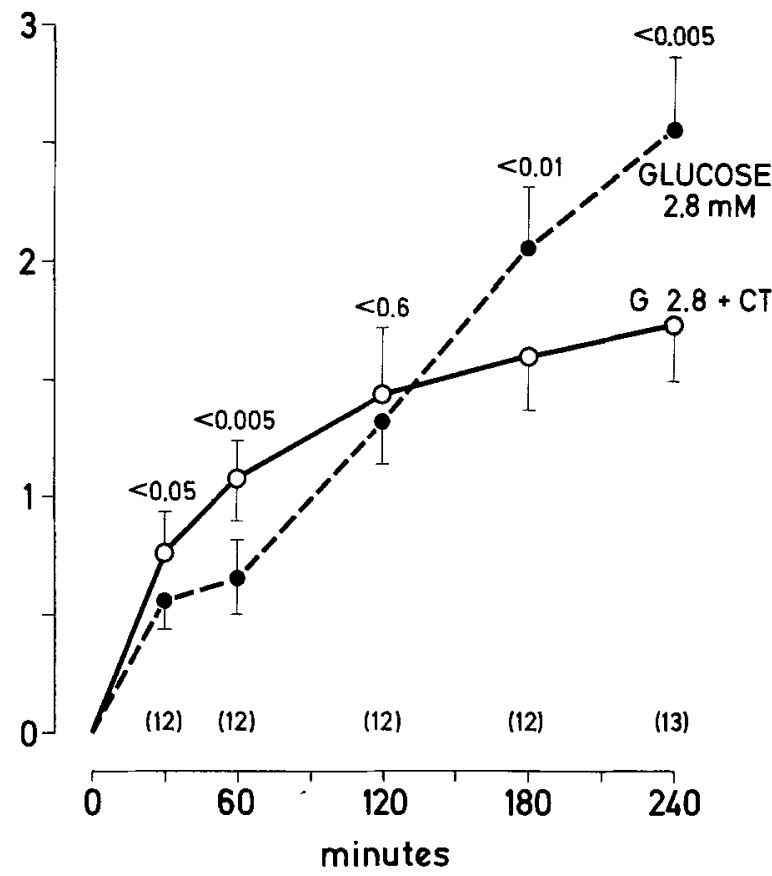

Fig. 2. Time course of the effect of cholera toxin $\left(1.2 \times 10^{-8} \mathbf{M}\right)$ on glucagon release in the presence of $2.8 \mathrm{mM}$ glucose and $2.5 \mathrm{mM}$ $\mathrm{Ca}^{++}$. Vertical lines represent \pm SEM. The number of experiments is indicated in parenthesis. The $p$ values above the lines were obtained by paired comparison at the different time points. CT, cholera toxin

gon release [47] the effect of cyclic AMP was examined in the presence of different concentrations of $\mathrm{Ca}^{++}$. Release was measured at $2.8 \mathrm{mM}$ glucose and with or without $10 \mathrm{mM}$ cyclic AMP over $30 \mathrm{~min}$ and $2 \mathrm{~h}$. Pooled data derived from several series of experiments are shown in Fig. 4 and expressed as the increment or decrement of glucagon released relative to control cultures in the absence of cyclic AMP. It can be seen that in calcium depleted media or in the presence of $0.3 \mathrm{mM} \mathrm{Ca}^{++}$no effect of cyclic AMP was detected at either $30 \mathrm{~min}$ or at $2 \mathrm{~h}$. With $1.0 \mathrm{mM} \mathrm{Ca}^{++}$ in the medium the amount of glucagon released by cyclic AMP in 30 min was significantly stimulated and more than double that of the controls while no significant increase was detected after $2 \mathrm{~h}$. By contrast, with $2.5 \mathrm{mM} \mathrm{Ca}^{++}$in the medium, cyclic AMP failed to stimulate release during the first $30 \mathrm{~min}$ and at 60 min (latter not shown), but caused a significant decrease in release of glucagon over $2 \mathrm{~h}$. Therefore, in 


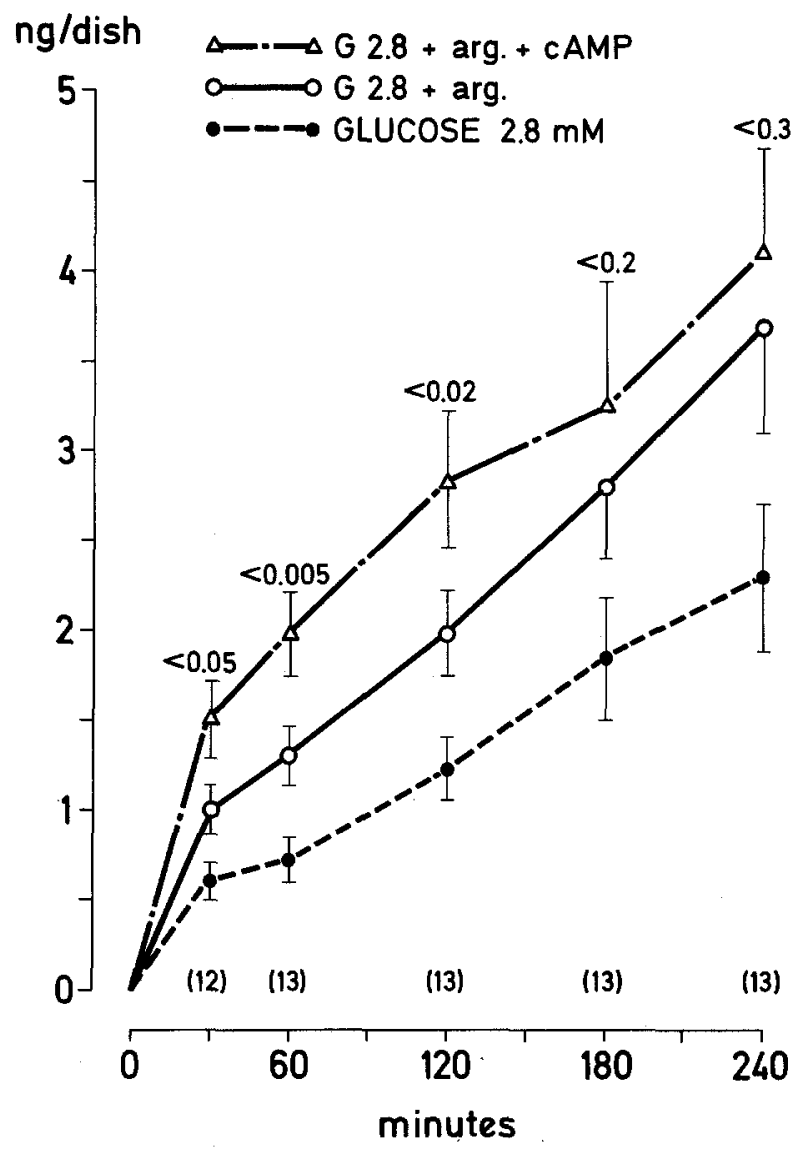

Fig. 3. Time course of the effect of cholera toxin on arginine-stimulated glucagon release. Arginine $(10 \mathrm{mM})$ and cholera toxin $\left(1.2 \times 10^{-8} \mathrm{M}\right)$ were tested in the presence of $2.8 \mathrm{mM}$ glucose and $2.5 \mathrm{mM} \mathrm{Ca}^{++}$. Vertical lines represent $\pm \mathrm{SEM}$. The $\mathrm{p}$ values above the lines were obtained by paired comparison of the differences in glucagon release in the presence of either arginine alone or the combination of arginine and cholera toxin. Statistical analysis of the effect of arginine relative to $2.8 \mathrm{mM}$ glucose is given in the text. The number of experiments is indicated in parenthesis. CT, cholera toxin

this large series of observations it was possible to detect the inhibitory effect of cyclic AMP as early as $2 \mathrm{~h}$ after the start of the incubation.

Following these experiments a time course study was performed of the effect of cyclic AMP on glucagon release in the presence of $1.0 \mathrm{mM} \mathrm{Ca}^{++}$. From the results of this study, shown in Fig. 5, the early stimulatory effect of cyclic AMP can be clearly seen. The amount of glucagon released under these conditions is almost three times that of the control release during the first $30 \mathrm{~min}$. Between $30 \mathrm{~min}$ and $2 \mathrm{~h}$ the rate of glucagon release in the presence of cyclic AMP slowed markedly so that no difference in release was detectable at $2 \mathrm{~h}$. Similarly at $4 \mathrm{~h}$ no difference in glucagon release was noted. Thus an important influ-

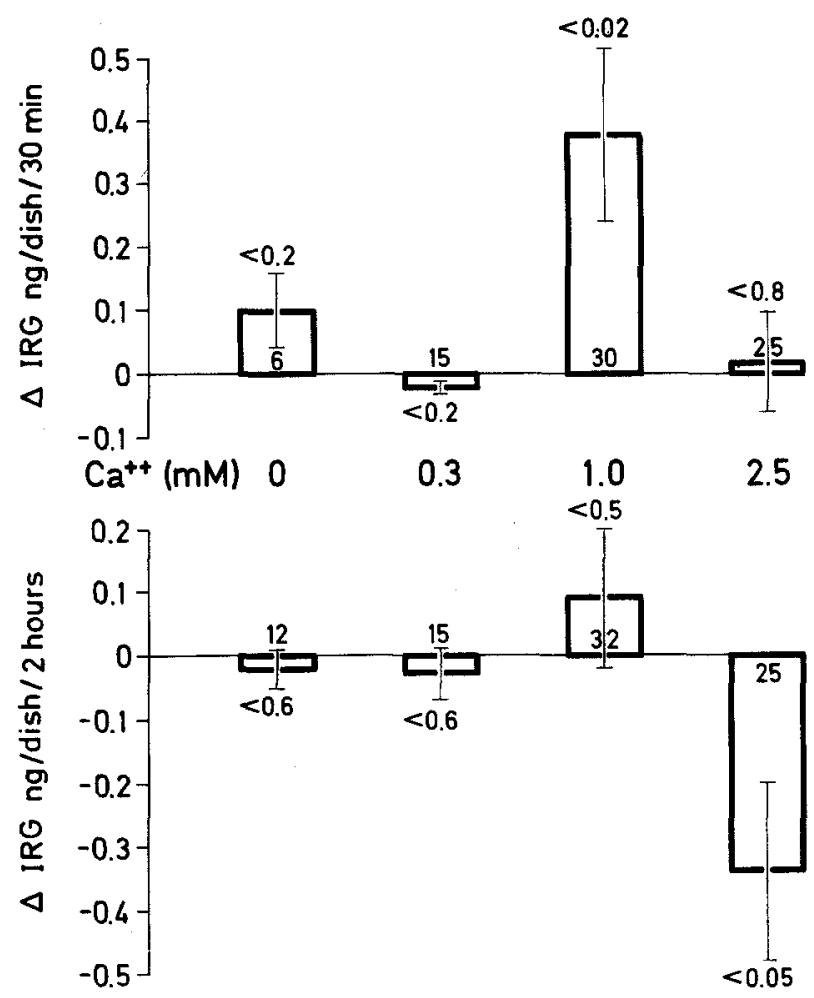

Fig. 4. Effect of different concentrations of $\mathrm{Ca}^{++}$on glucagon release in the presence or absence of cyclic AMP $(10 \mathrm{mM})$. The concentration of glucose was $2.8 \mathrm{mM}$ throughout. The results are expressed as the increment or decrement in glucagon release relative to control dishes, i.e. $\triangle \mathrm{ng}$ IRG released $/ \mathrm{dish} / 30 \mathrm{~min}$ (upper panel) or $\triangle \mathrm{ng}$ IRG released/dish $/ 2 \mathrm{hr}$ (lower panel). In control dishes glucagon release increased as a function of time (0-120 $\mathrm{min}$ ) at each $\mathrm{Ca}^{++}$concentration. Vertical lines represent \pm SEM $p$ values were obtained by paired comparison. The number of experiments is indicated in or above each bar. IRG, immunoreactive glucagon

ence of $\mathrm{Ca}^{++}$concentration on the A-cell response to cyclic AMP is apparent: firstly, the effect of cyclic AMP is dependent on $\mathrm{Ca}^{++}$as no effect is seen at low $\mathrm{Ca}^{++}$concentrations. Secondly, a stimulatory effect of cyclic AMP is observed in the presence of $1 \mathrm{mM} \mathrm{Ca}^{++}$ and thirdly, a late inhibitory effect in the presence of $2.5 \mathrm{mM} \mathrm{Ca}^{++}$.

\section{Discussion}

The results of this study show that, in the presence of $2.5 \mathrm{mM} \mathrm{Ca}^{++}$, cyclic AMP, dibutyryl cyclic AMP, theophylline and cholera toxin all inhibit glucagon release by monolayer cultures of rat pancreas when 


\section{$\mathrm{Ca}^{++} 1 \mathrm{mM}$}

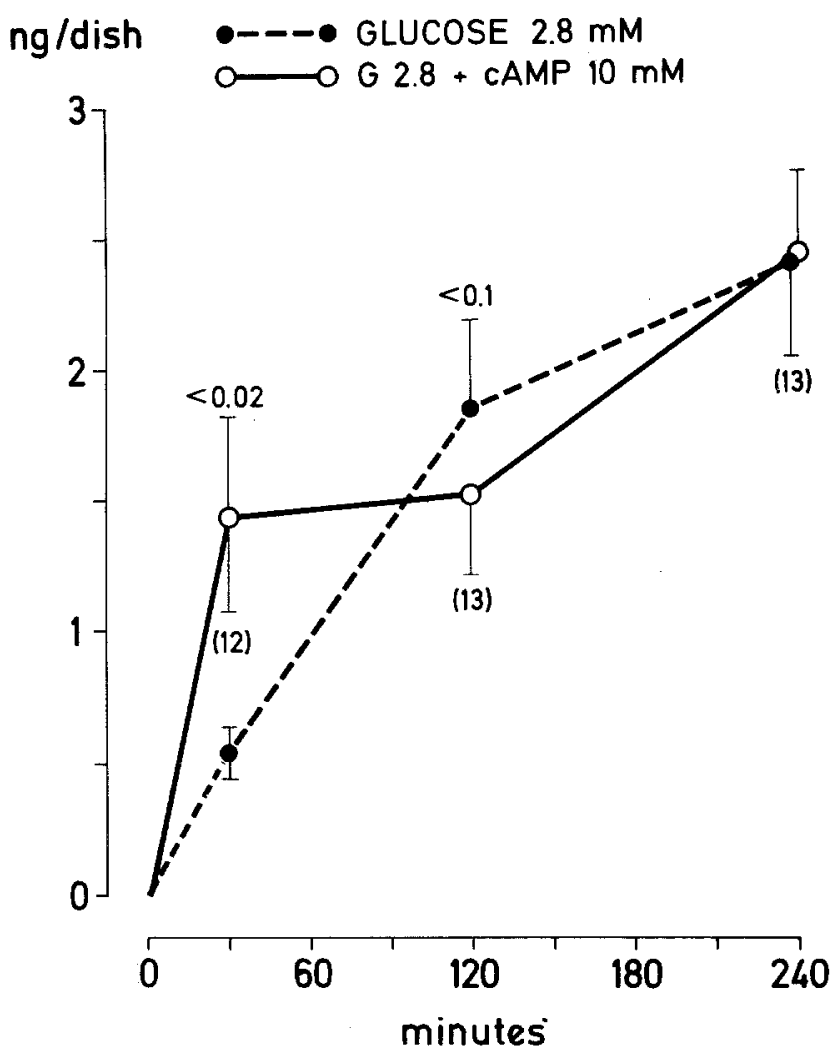

Fig. 5. Time course of the effect of cyclic AMP $(10 \mathrm{mM})$ on glucagon release in the presence of $1 \mathrm{mM} \mathrm{Ca}^{++}$. The concentration of glucose was $2.8 \mathrm{mM}$. Vertical lines represent \pm SEM. p values were obtained by paired comparison at the different time points. The number of experiments is indicated in parenthesis

measured over four hours. From the fact that raising intracellular cyclic AMP levels by these different techniques, namely addition of exogenous cyclic AMP, inhibition of phosphodiesterase and stimulation of adenylate cyclase all produce the same effect, it can be assumed that the inhibitory effect on glucagon release is indeed due to intracellular cyclic AMP. The inhibition is concentration dependent and specific in that AMP, ADP and ATP did not inhibit the release. Adenosine, which did inhibit glucagon release has been reported to stimulate the accumulation of cyclic AMP in some tissues $[48,49,50]$ but not in others [51]. The former finding $[48,49,50]$ may explain the cyclic AMP-like effect of adenosine in the present study. The stimulation of glucagon release by ATP is unexplained but ATP has been shown previously to stimulate insulin release [52]. Weir and co-workers found adenosine, AMP, and ADP to stimulate glucagon release in the perfused rat pancreas, but in their preparation ATP had no stimulating effect [34].
The time course studies using exogenous cyclic AMP and cholera toxin demonstrate that the inhibition does not have an early onset but develops gradually, as the incubation proceeds. Cholera toxin exhibited a different pattern of effect from cyclic AMP in that an early stimulation of glucagon release was seen at 30 and $60 \mathrm{~min}$. At four hours, however, the inhibition of glucagon release was clearly seen; the inhibitory effect began at $2 \mathrm{~h}$. The ability of cholera toxin to elicit an early stimulation of glucagon release may reflect the advantage of raising cyclic AMP levels by stimulation of adenylate cyclase in the cells rather than by the exogenous addition of large and nonphysiological amounts of cyclic AMP. Similarly, we find that theophylline produces an early stimulation (unpublished data). The assumption that cyclic AMP levels in the cultured A-cells are elevated after four hours of incubation with cholera toxin is supported by time-course studies of the effect of the toxin on adenylate cyclase in various tissues. Thus in cultured melanoma cells the adenylate cyclase activity increased gradually over the initial $5 \mathrm{~h}$ after exposure to the toxin and remained stimulated for several days [53].

In examining the effects of exogenous cyclic AMP and cholera toxin on arginine-stimulated glucagon release, it was found that both agents behave similarly and no inhibition of glucagon release was detected. Instead, both agents stimulated the release over the first hour of incubation. Thus arginine appeared to protect the A-cells against the inhibitory effect of cyclic AMP and only the early stimulatory effect was seen. This agrees with the report by Jarrousse and Rosselin [36] that dibutyryl cyclic AMP and theophylline enhanced amino acid induced glucagon release, but is at variance with the findings of Marco et al.[54], who observed an inhibitory effect of aminophylline on arginine-induced glucagon release in vivo.

The evidence dicussed so far suggests that in the presence of $2.5 \mathrm{mM} \mathrm{Ca}^{++}$, raising intracellular cyclic AMP levels can cause an early stimulation of glucagon release (with cholera toxin) followed by a late inhibition. Most striking is the fact that the effects of cyclic AMP can be influenced dramatically by the $\mathrm{Ca}^{++}$ concentration in the medium. From the responses obtained with different concentrations of $\mathrm{Ca}^{++}$it follows that $\mathrm{Ca}^{++}$exerts a strong controlling influence over the effects of cyclic AMP on glucagon release. At very low $\mathrm{Ca}^{++}$concentrations, no effect of cyclic AMP on glucagon release can be detected. With 1.0 $\mathrm{mM} \mathrm{Ca}{ }^{++}$stimulation by cyclic AMP is seen at $30 \mathrm{~min}$ but not at $2 \mathrm{~h}$, while with $2.5 \mathrm{mM} \mathrm{Ca}^{++}$no stimulation occurs at $30 \mathrm{~min}$ and inhibition of glucagon release is observed at $2 \mathrm{~h}$. 
The mechanism underlying these effects is obscure, but they are in line with recent observations of the effect of $\mathrm{Ca}^{++}$on glucagon release when $\mathrm{Ca}^{++}$ entry into the A-cells is facilitated by the divalent cation ionophore A23187. In these studies, low medium $\mathrm{Ca}^{++}$concentrations in the presence of the ionophore were found to stimulate glucagon release, while high concentrations were found to be inhibitory [47]. It may be speculated, therefore, that if raised intracellular $\mathrm{Ca}^{++}$is responsible for the stimulation of glucagon release then this may be the mechanism by which cyclic AMP stimulates the release process. However, in the presence of $2.5 \mathrm{mM} \mathrm{Ca}^{++}$in the medium the increase in intracellular $\mathrm{Ca}^{++}$may be too great, at least over a two hour period, so that inhibition of key enzymes involved in the release process may result in decreased glucagon release. Under physiological conditions with normal plasma $\mathrm{Ca}^{++}$, it may be assumed that the effect of increasing intracellular cyclic AMP concentrations will be a stimulation of glucagon release.

Acknowledgements. The authors are grateful to Mrs. Theres Cuche, Mrs. Pascale Demay, Mrs. Marie-Paule Barrillat and Miss Marie-France Blanc for their skilled technical assistance. These studies were supported by the Fonds National Suisse de la Recherche Scientifique (grants 3.1060.73, 3.541.71, $3.8080 .72,3.0280 .73,3.0310 .73)$.

\section{References}

1. Meguid, M. M., Brennan, M. F., Müller, W. A., Aoki, T. T.: Glucagon and trauma. Lancet 1972 II, 1145

2. Willerson, J. T., Hutcheson, D., Leshin, S. J., Faloona, G. R., Unger, R. H.: Serum glucagon and insulin levels and their relationship to blood glucose values in patients with acute myocardial infraction and acute coronary insufficiency. Amer. J. Med. 57, 747-753 (1974)

3. Bloom, S. R., Daniel, P. M., Johnson, D. I., Ogawa, O., Pratt, O. E.: Changes in glucagon level associated with anxiety or stress. Psychol. Med. 2, , 426-427 (1972)

4. Bloom, S. R., Daniel, P. M., Johnson, D. I., Ogawa, O., Pratt, O. E.: Release of glucagon induced by stress. Quart. J. exp. Physiol. 58, 99-102 (1973)

5. Böttger, I., Faloona, G. R., Knochel, J. P., Unger, R. H.: The effect of exercise on glucagon secretion. J. clin. Endocr. 35, 117-125 (1972)

6. Felig, P., Wahren, J., Hendler, R., Ahlborg, G.: Plasma glucagon levels in exercising man. New Engl. J. Med. 287, 184-185 (1972)

7. Luyckx, A. S., Lefebvre, P. J.: Mechanisms involved in the exercise-induced increase in glucagon secretion in rats. Diabetes 23, 81-93 (1974)

8. Unger, R. H., Eisentraut, A. M., McCall, M. S., Madison, L. L.: Measurements of endogenous glucagon in plasma and the influence of blood glucose concentration upon its secretion. J. clin. Invest. 41, 682-689 (1962)
9. Ohneda, A., Arguilar-Parada, E., Eisentraut, A. M., Unger, R. $H$.: Control of pancreatic glucagon secretion by glucose. Diabetes 18, 1-10 (1969)

10. Gerich, J. E., Schneider, V., Dippe, S. E., Langlois, M., Noacco, C., Karam, J. H., Forsham, P. H.: Characterization of the glucagon response to hypoglycemia in man. J. clin. Endocr. 38, 77-82 (1974)

11. Bloom, S. R., Edwards, A. V., Vaugham, N. J. A.: The role of the autonomic innervation in the control of glucagon release during hypoglycemia in the calf. J. Physiol. 286, 611-623 (1974)

12. Rocha, D. M., Santeusanio, F., Faloona, G. R., Unger, R. H.: Abnormal pancreatic alpha-cell function in bacterial infections. New Engl. J. Med. 288, 700-703 (1973)

13. Assan, R., Hautecouverture, G., Guillemant, S., Dauchy, F., Protin, P., Dérot, M.: Evolution de paramètres hormonaux (glucagon, cortisol, hormone somatotrope) énergétiques (glucose, acides gras, glycérol libre) dans dix acidocétoses diabétiques graves traitées. Path. et Biol. 17, 1095 (1969)

14. Müller, W. A., Faloona, G. R., Unger, R. H.: Hyperglucagonemia in diabetic ketoacidosis. Its prevalence and significance. Amer. J. Med. 54, 52-57 (1973)

-15. Aguilar-Parada, E., Eisentraut, A. M., Unger, R. H.: Effect of starvation on plasma pancreatic glucagon in normal man. Diabetes 18, 717-723 (1969)

16. Marliss, E. B., Aoki, T. T., Unger, R. H., Soeldner, J. S., Cahill, G. F. Jr.: Glucagon levels and metabolic effects in prolongedfasted man. J. clin. Invest. 49, 2256-2270 (1970)

17. Kaneto, A., Miki, E., Kosaka, K.: Effects of vagal stimulation on glucagon and insulin secretion. Endocrinology 95, 1005-1010 (1974)

18. Marliss, E. B., Girardier, L., Seydoux, J., Wollheim, C. B., Kanazawa, Y., Orci, L., Renold, A. E., Porte, D., Jr.: Glucagon release induced by pancreatic nerve stimulation in the dog. J. clin. Invest. 52, 1246-1259 (1973)

19. Bloom, S. R., Edwards, A. V., Vaugham, N. J. A.: The role of the sympathetic innervation in the control of plasma glucagon concentration in the calf. J. Physiol. 233, 457-466 (1973)

20. Iversen, J.: Effect of acetyl choline on the secretion of glucagon and insulin from the isolated, perfused canine pancreas. Diabetes 22, 381-387 (1973)

21. Leclercq-Meyer, V., Brisson, G. R., Malaisse, W. J.: Effect of adrenaline and glucose on release of glucagon and insulin in vitro. Nature (Lond.) New Biol. 231, 248-249 (1971)

22. Iversen, J.: Adrenergic receptors and the secretion of glucagon and insulin from the isolated perfused canine pancreas. J. clin. Invest. 52, 2102-2116 (1973)

23. Marliss, E. B., Wollheim, C. B., Blondel, B., Orci, L., Lambert, A. E., Stauffacher, W., Like, A. A., Renold, A. E.: Insulin and glucagon release from monolayer cell cultures of pancreas from newborn rats. Europ. J. clin. Invest. 3, 16-26 (1973)

24. Weir, G. L., Knowlton, S. D., Martin, D. B.: Glucagon secretion from the perfused rat pancreas. Studies with glucose and catecholamines. J. clin. Invest. 54, 1403-1412 (1974)

25. Gerich, J. E., Lovinger, R., Grodsky, G. M.: Inhibition by somatostatin of glucagon and insulin release from the perfused rat pancreas in response to arginine isoproterenol and theophylline: Evidence for a preferential effect on glucagon secretion. Endocrinology 96, 749-754 (1975)

26. Samols, E., Tyler, J. M., Kajinuma, H.: Influence of the sulfonamides on pancreatic humoral secretion and evidence for an insulin-glucagon feed-back system. Diabetes. Excerpta Med. Int. Congr. Ser. (Amst.) 231, 636-655 (1971)

27. Gerich, J. E., Karam, J. H., Forsham, P. H.: Stimulation of glucagon secretion by epinephrine in man. J. clin. Endocr. 37, 479-481 (1973)

28. Gerich, J. E., Langlois, M., Noacco, L., Schneider, V., Forsham, 
P. H.: Adrenergic modulation of pancreatic glucagon secretion in man. J. clin. Invest. 53, 1441-1446 (1974)

29. George, D. T., Rayfield, E. J.: L-DOPA-induced plasma glucagon release. J. clin. Endocr. 39, 618-621 (1974)

30. Rabinovitch, A., Seydoux, J., Girardier, L.: Stimulation of glucagon release and inhibition of insulin release by sympathetic nerve stimulation in the dog. Diabetologia 10, 398 (Abstr.) (1974)

31. Lindsey, C. A., Faloona, G. R., Unger, R. H.: Plasma glucagon levels during rapid exsanguination with and without adrenergic blockade. Diabetes 24, 313-316 (1975)

32. Howell, S. L., Edwards, J. C., Montague, W.: Regulation of adenylate cyclase and cyclic-AMP dependent protein kinase activities in $\mathrm{A}_{2}$-cell rich guinea-pig islets of Langerhans. Horm. Metab. Res. 6, 49-52 (1974)

33. Iversen, J.: Effect of different non-metabolizable hexoses on the secretion of insulin and glucagon from the isolated perfused canine pancreas. Diabetologia 9, 72 (Abstr.) (1973)

34. Weir, G. C., Knowlton, S. D., Martin, D. B.: Nucleotide and nucleoside stimulation of glucagon secretion. Endocrinology 97, 932-936 (1975)

35. Braaten, J. T., Schenk, A., Lee, M. J., McGugan, J. E., Mintz, D. H.: Cyclic nucleotide-mediated secretion of glucagon and gastrin in monolayer culture of rat pancreas. J. clin. Invest. 53, 10a (Abstr.) (1974)

36. Jarrousse, Cl, Rosselin, G.: Interaction of amino acids and cyclic AMP on the release of insulin and glucagon by newborn rat pancreas. Endocrinology 96, 168-177 (1975)

37. Chesney, T. McC., Schofield, J. G.: Studies on the secretion of pancreatic glucagon. Diabetes 18, 527-532 (1969)

38. Frankel, B. J., Gerich, J. E., Hagura, R., Fanska, R. E., Gerritsen, G. C., Grodsky, G. M.: Abnormal secretion of insulin and glucagon by the in vitro perfused pancreas of the genetically diabetic Chinese Hamster. J. clin. Invest. 53, 1647-1656 (1974)

39. Wollheim, C. B., Blondel, B., Rabinovitch, A., Renold, A. E.: Insulin and glucagon release in pancreatic monolayer cultures: Effect of cyclic nucleotides. Int. Diab. Fed. VIII Congr. Excerpta Med. Int. Congr. Ser. (Amst.) 280, 48-49 (Abstr.) (1973)

40. Toyota, T., Sato, S.-I., Kudo, M., Abe, K., Goto, Y.: Secretory regulation of endocrine pancreas: Cyclic AMP and glucagon secretion. J. clin. Endocr. 41, 81-89 (1975)

41. Hahn, H.-J., Hellman, B., Lernmark, Å., Sehlin, J., Täljedal I-B.: The pancreatic $\beta$-cell recognition of insulin secretagogues. Influence of neuraminidase treatment on the release of insulin and the islet content of insulin, sialic acid, and cyclic adenosine $3^{\prime}: 5^{\prime}$-monophosphate. J. biol. Chem. 249, 5275-5284 (1974)

42. Lambert, A. E., Blondel, B., Kanazawa, Y., Orci, L., Renold, A. E.: Monolayer cell-culture of neonatal rat pancreas. Light microscopy and evidence of immunoreactive insulin synthesis and release. Endocrinology 90, 239-248 (1972)

43. Wollheim, C. B., Blondel, B., Trueheart, P. A., Renold, A. E. Sharp, G. W. G.: Calcium-induced insulin release in monolayer culture of the endocrine pancreas. Studies with ionophore A23187. J. biol. Chem. 250, 1354-1360 (1975)

44. Orci, L., Like, A. A., Amherdt, M., Blondel, B., Kanazawa, Y., Marliss, E. B., Lambert, A. E., Wollheim, C. B., Renold, A. E.: Monolayer cell culture of neonatal rat pancreas: An ultrastructural and biochemical study of functioning endocrine cells. J. Ultrastruct. Res. 43, 270-297 (1973)

45. Unger, R. H., Aguilar-Parada, E., Müller, W. A., Eisentraut, A. M.: Studies on pancreatic alpha-cell function in normal and diabetic subjects. J. clin. Invest. 49, 837-848 (1970)

46. Finkelstein, R. A., Lospalluto, J. J.: Production of highly purified choleragen and choleragenoid. J. infect. Dis. 121, (Suppl.), 63 (1970)

47. Wollheim, C. B., Blondel, B., Renold, A. E., Sharp, G. W. G.: Calcium induced glucagon release in monolayer culture of the endocrine pancreas. Studies with ionophore A23187. Diabetologia (in press 1976)

48. Sattin, A., Rall, T. W.: The effect of adenosine and adenine nucleotides on the cyclic adenosine $3^{\prime}, 5^{\prime}$ phosphate content of guinea-pig cerebral cortex slices. Molec. Pharmacol. 6, 13-23 (1970)

49. Shimizu, H., Creveling, C. R., Daly, J.: Stimulated formation of adenosine $3^{\prime}-5^{\prime}$ cyclic phosphate in cerebral cortex. Synergism between electrical activity and biogenic amines. Proc. nat. Acad. Sci. (Wash.) 65, 1033-1040 (1970)

50. Haslam, R. J., Lynham, J. A.: Activation and inhibition of blood platelet adenylate cyclase by adenosine or by 2-chloroadenosine. Life Sci. 11, II: 1143-1154 (1972)

51. Fain, J. N., Pointer, R. H., Ward, W. F.: Effects of adenosine nucleosides on adenylate cyclase, phosphodiesterase, cyclic adenosine monophosphate accumulation and lipolysis in fat cells. J. biol. Chem. 247, 6866-6872 (1972)

52. Sussman, K. E., Vaughan, G. O., Stjernholm, M. R.: Factors controlling insulin secretion in the perfused, isolated rat pancreas. Diabetes. Excerpta Med. Int. Congr. Ser. (Amst.) 172, 123-137 (1969)

53. O'Keefe, E., Cuatrecasas, P.: Cholera toxin mimics melanocyte stimulating hormone in inducing differentiation in melanoma cells. Proc. nat. Acad. Sci. (Wash.) 71, 2500-2504 (1974)

54. Marco, J., Diaz-Fierros, M., Baroja, I. M., Villanueva, M. M., Valverde, I.: Opposite effects of aminophylline on arginine-induced glucagon and insulin secretion in humans. Diabetes 21, 289-294 (1972)

Received: December 12, 1975, and in revised form: April 14, 1976

Dr. C. B. Wollheim

Institut de Biochimie Clinique

Sentier de la Roseraie

Ch-1211 Genève 4

Switzerland 